\title{
Bacteria Broadly-Resistant to Last Resort Antibiotics Detected in Commercial Chicken Farms
}

\author{
Jared M. Jochum 1,2 (D), Graham A. J. Redweik ${ }^{1,2}$, Logan C. Ott ${ }^{1,2}$ ad and Melha Mellata $1,2, *(\mathbb{D})$ \\ 1 Department of Food Science and Human Nutrition, College of Agriculture and Life Science, \\ Iowa State University, Ames, IA 50011, USA; jmjochum@iastate.edu (J.M.J.); gredweik@iastate.edu (G.A.J.R.); \\ ott@iastate.edu (L.C.O.) \\ 2 Interdepartmental Microbiology Graduate Program, Iowa State University, Ames, IA 50011, USA \\ * Correspondence: mmellata@iastate.edu
}

Citation: Jochum, J.M.; Redweik, G.A.J.; Ott, L.C.; Mellata, M. Bacteria Broadly-Resistant to Last Resort Antibiotics Detected in Commercial Chicken Farms. Microorganisms 2021, 9, 141. https://doi.org/10.3390/ microorganisms 9010141

Received: 20 December 2020

Accepted: 6 January 2021

Published: 9 January 2021

Publisher's Note: MDPI stays neutral with regard to jurisdictional clai$\mathrm{ms}$ in published maps and institutional affiliations.

Copyright: () 2021 by the authors. Licensee MDPI, Basel, Switzerland. This article is an open access article distributed under the terms and conditions of the Creative Commons Attribution (CC BY) license (https:// creativecommons.org/licenses/by/ $4.0 /)$.

\begin{abstract}
Resistance to last resort antibiotics in bacteria is an emerging threat to human and animal health. It is important to identify the source of these antimicrobial resistant (AMR) bacteria that are resistant to clinically important antibiotics and evaluate their potential transfer among bacteria. The objectives of this study were to (i) detect bacteria resistant to colistin, carbapenems, and $\beta$ lactams in commercial poultry farms, (ii) characterize phylogenetic and virulence markers of E. coli isolates to potentiate virulence risk, and (iii) assess potential transfer of AMR from these isolates via conjugation. Ceca contents from laying hens from conventional cage (CC) and cage-free (CF) farms at three maturity stages were randomly sampled and screened for extended-spectrum $\beta$-lactamase (ESBL)-producing Enterobacteriaceae, carbapenem-resistant Acinetobacter (CRA), and colistin resistant Escherichia coli (CRE) using CHROMagar ${ }^{\mathrm{TM}}$ selective media. We found a wide-spread abundance of CRE in both CC and CF hens across all three maturity stages. Extraintestinal pathogenic Escherichia coli phylogenetic groups B2 and D, as well as plasmidic virulence markers iss and iut A, were widely associated with AMR E. coli isolates. ESBL-producing Enterobacteriaceae were uniquely detected in the early lay period of both CC and CF, while multidrug resistant (MDR) Acinetobacter were found in peak and late lay periods of both CC and CF. CRA was detected in CF hens only. bla $\mathrm{CMY}$ was detected in ESBL-producing E. coli in CC and CF and MDR Acinetobacter spp. in CC. Finally, the $b l a_{C M Y}$ was shown to be transferrable via an IncK/B plasmid in CC. The presence of MDR to the last-resort antibiotics that are transferable between bacteria in food-producing animals is alarming and warrants studies to develop strategies for their mitigation in the environment.
\end{abstract}

Keywords: ESBL-producing Enterobacteriaceae; colistin resistant Escherichia coli; carbapenem-resistant Acinetobacter; hens; maturity stages; plasmid

\section{Introduction}

The rise of antimicrobial resistant (AMR) bacteria is a serious threat to human and animal health, as increasing resistance to commonly used antibiotic therapies have created a burden on treatment options [1]. AMR bacteria can arise in nature and are commonly found in food producing animals like poultry [2]. For instance, the gastrointestinal tract (GIT) of chickens and the facilities that house these poultry serve as reservoirs for AMR resistant bacteria $[3,4]$. Of these AMR bacteria, extended-spectrum $\beta$-lactamase (ESBL) producing Enterobacteriaceae, carbapenem-resistant Acinetobacter (CRA), and colistin resistant E. coli (CRE) are emerging AMR bacteria found in the poultry environment [5-7]. The Centers for Disease Control and Prevention (CDC) lists ESBL-producing Enterobacteriaceae and CRA as serious and urgent threats, respectively [8]. Although not explicitly listed as an antibiotic resistant threat by the $\mathrm{CDC}$, colistin resistance is clinically relevant given its use as a last resort antibiotic for treating multidrug resistant (MDR) infections [9]. As poultry is one of the most consumed meat sources globally [10], it is crucial to identify the presence and 
prevalence of these AMR populations in the poultry environment and understand the spread of these resistances to other bacteria.

Bacteria primarily acquire AMR genes by horizontal gene transfer (HGT), a leading contributor to bacterial coevolution [11]. Conjugative plasmids are responsible for HGT of virulence and AMR genes, which has led to the rapid rise of AMR in bacterial pathogens [12,13]. Recently, the transfer of mobile colistin resistance $(\mathrm{mcr}$ ) and ESBL-producing genes have been linked to a variety of plasmid types and bacterial hosts in the poultry environment [14,15]. As AMR populations persist in the poultry environment, there is an increased risk that pathogens might acquire AMR genes.

Although E. coli and Acinetobacter are commensal gut bacteria in poultry and are detected in the feed, feces, and environment of poultry facilities, both E. coli and Acinetobacter have the potential to cause extraintestinal diseases in both humans and poultry [16-22]. Importantly, extraintestinal pathogenic E. coli (ExPEC) infections are often highly fatal in humans and poultry and are increasing worldwide, imposing a major burden on public health [23]. As pooling of these potential pathogens and AMR genes are taking place in poultry, it is important to detect both AMR genes and associated virulence markers that can identify potential pathogens. There are limited studies that investigate the role of production environments (i.e., conventional cage $[\mathrm{CC}]$ versus cage-free $[\mathrm{CF}]$ ) and maturity stages (i.e., early, peak, and late lay) on AMR emergence. In commercial farms, layer hens can be categorized by the period in which egg production begins (early), is at its highest (peak), and later diminishes due to age (late). Studies have shown that the maturity stage of layer hens can impact the colonization and shedding of particular bacteria and the diversity of bacteria inhabiting the GIT $[24,25]$. Recently, our study has shown that different layer maturity stages exhibit differing levels of Enterobacteriaceae in CC and CF conditions [26]. We thus hypothesized that both environment and maturity may play a role in AMR diversity and potential virulence detection.

In this study, we examined ceca contents from hens in commercial CC and CF environments as potential reservoirs for CRA, CRE, and ESBL-producing Enterobacteriaceae. Potential spread of these resistances was examined as well as the virulence potential of E. coli isolates. We were able to identify MDR Acinetobacter, ESBL-producing E. coli, and widespread presence of CRE in both CC and CF environments. Phylogenetic and virulence screening identified possibly MDR ExPEC isolates in both environments. Finally, AMR was demonstrated to be transferable in the CC environment via plasmid mediated HGT.

\section{Materials and Methods}

\subsection{Source Material}

Ceca contents from hens in two commercial farms (CC and CF) located in Iowa were previously sampled, flash frozen, and stored at $-80^{\circ} \mathrm{C}$ between May and September of 2017 [24]. Samples were collected from three laying stages: (i) early lay (17-23 weeks), (ii) peak lay (25-39 weeks), and (iii) late lay (64-88 weeks) from the CC and CF commercial farms in Iowa. A total of 20 hens were randomly sampled for each maturity group in each facility $(\mathrm{N}=20 \times 3$ maturities $\times 2$ facilities $=120$ total $)$. The samples were analyzed as described in (Figure 1) and detailed below. 


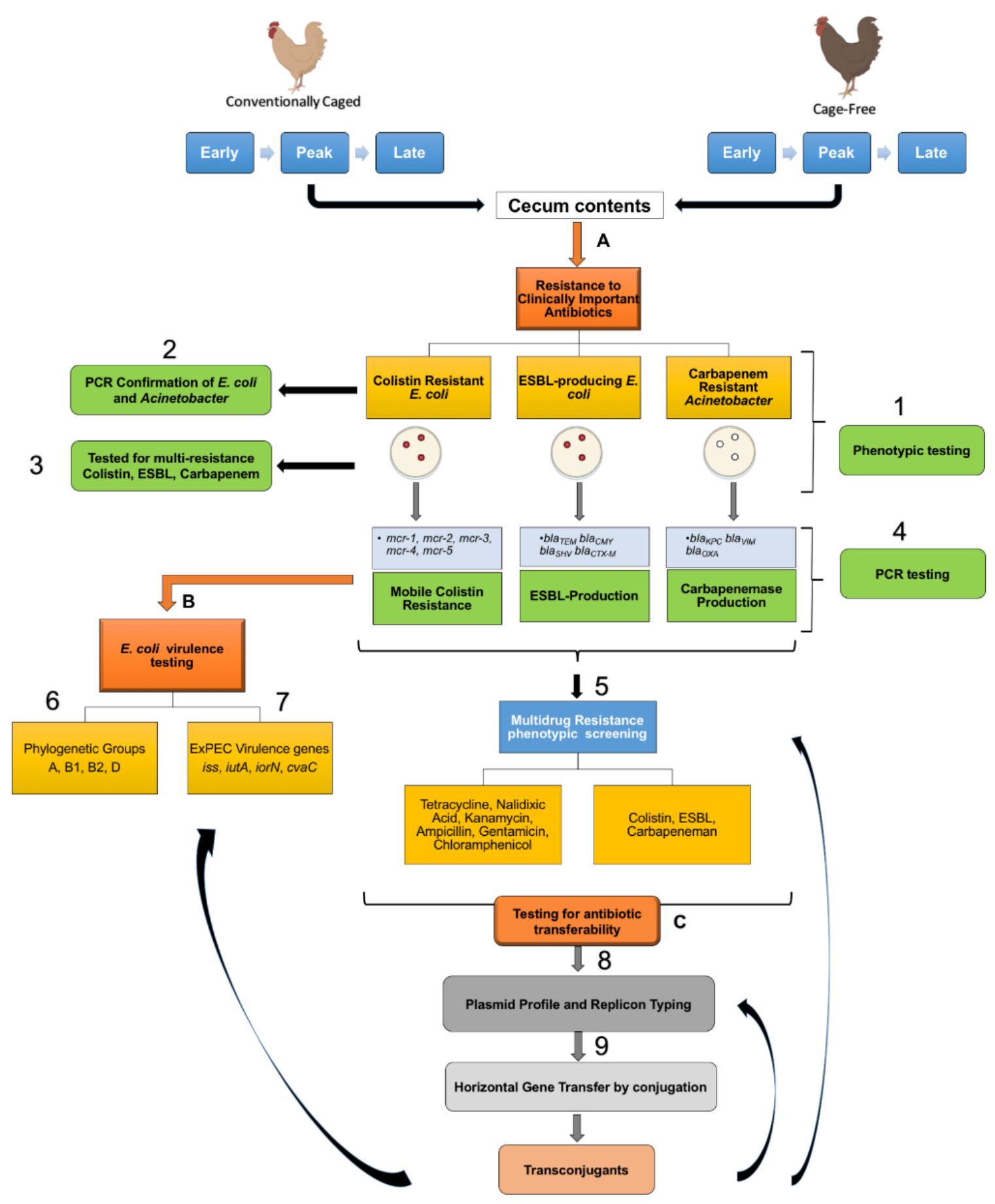

Figure 1. Graphic description of sample analysis. Ceca contents from hens at different maturity stages (early, peak, and late) from conventional cage and cage-free poultry farms were analyzed for (A) resistance to clinically important antibiotics, (B) E. coli virulence genes and phylotype, and (C) plasmid profiles and transferability.

\subsection{Identification of Last Resort Antibiotic-Resistant Isolates}

Initially, $0.2 \mathrm{~g}$ ceca content samples were resuspended in $200 \mu \mathrm{L}$ of sterile PBS, and $20 \mu \mathrm{L}$ of suspensions were then added to CHROMagar COL-APSE ${ }^{\mathrm{TM}}$ (Paris, France) media for the selection of colistin-resistant bacteria. For enrichment of AMR bacteria, original suspensions were mixed with $500 \mu \mathrm{L}$ Luria-Bertani broth $(0.1 \%$ glucose $)$ and incubated overnight at $37^{\circ} \mathrm{C}$. Thereafter, $20 \mu \mathrm{L}$ of enriched suspensions were pipetted onto CHROMagar Orientation ${ }^{\mathrm{TM}}$ agar (Paris) to detect ESBL-producing Enterobacteriaceae and CHROMagar 
SuperCARBA ${ }^{\mathrm{TM}}$ (Paris) to detect carbapenem-resistant bacteria. Plates were incubated at $37^{\circ} \mathrm{C}$ for up to $48 \mathrm{~h}$ to allow for the growth of slow growing bacteria like Acinetobacter spp. [27]. Initially, isolates were speculatively speciated by color change on the CHROMagar $^{\mathrm{TM}}$ media according to manufacturer's instructions. Colistin resistant bacteria were enumerated, and cultures from individual colonies were stored in glycerol solution at $-80{ }^{\circ} \mathrm{C}$ for future experiments. Colistin resistance was confirmed by growth on MuellerHinton agar (MHA) (4 mg/L colistin). Colonies from CHROMagar OrientationTM were later tested on CHROMagar COL-APSETM and SuperCARBA ${ }^{\mathrm{TM}}$ to evaluate multiple resistance. Colonies from CHROMagar SuperCARBA ${ }^{\mathrm{TM}}$ were later tested on CHROMagar COL-APSE ${ }^{\mathrm{TM}}$ and Orientation ${ }^{\mathrm{TM}}$ respectively to evaluate multiple resistance. DNA was extracted from all colistin resistant and ESBL-producing bacteria as described [28] and were screened via polymerase chain reaction (PCR) for the E. coli housekeeping gene, uidA (Table S1). White/cream colonies isolated from CHROMagar Orientation ${ }^{\mathrm{TM}}$ and Super$\mathrm{CARBA}^{\mathrm{TM}}$ media were speculatively designated as Acinetobacter spp., DNA was extracted, and isolates were confirmed by PCR amplification of the Acinetobacter spp. specific $16 \mathrm{~S}$ rRNA gene (Table S1) [29]. All positively identified CRE, ESBL-producing E. coli and Acinetobacter, and CRA were thereafter screened for resistance to rifampicin $(100 \mu \mathrm{g} / \mathrm{mL})$, tetracycline $(15 \mu \mathrm{g} / \mathrm{mL})$, nalidixic acid $(30 \mu \mathrm{g} / \mathrm{mL})$, ampicillin $(50 \mu \mathrm{g} / \mathrm{mL})$, kanamycin $(50 \mu \mathrm{g} / \mathrm{mL})$, gentamicin $(20 \mu \mathrm{g} / \mathrm{mL})$, and chloramphenicol $(20 \mu \mathrm{g} / \mathrm{mL})$. $\beta$-lactamase production was confirmed through resistance to third generation cephalosporins (cefotaxime and ceftazidime) via Clinical and Laboratory Standards Institute (CLSI) guidelines [30]. Furthermore, minimum inhibitory concentration (MIC) of colistin, cefotaxime, and ceftazidime were obtained via agar dilution using CLSI breakpoints [28]. For all antibiotic resistance assays, E. coli K-12 strain MG1655 was used as a negative control. PCRs were performed to identify the presence of various $\mathrm{mcr}$ genes, multiple $\beta$-lactamase encoded genes, and carbapenemase encoded genes (Table S1). ESBL and mcr multiplexes were utilized as described previously [31,32]. NCBI Primer-blast was used to generate bla pairs (https: / / www.ncbi.nlm.nih.gov/tools/primer-blast/). Positive control strains used in this portion of the study were supplied from the CDC \& FDA Antibiotic Resistance Bank (Table S2).

\subsection{Plasmid Profiling and Typing}

CRE, ESBL-producing E. coli and Acinetobacter, and CRA isolates were streaked onto LB agar plates and incubated overnight. Individual colonies from overnight plates were suspended in $3 \mathrm{~mL}$ LB broth $(0.1 \%$ glucose $)$ and shaken overnight at $37^{\circ} \mathrm{C}$. Plasmid extraction was performed using phenol: chloroform-based method as described previously [33]. The resulting plasmid extracts were loaded into $0.5 \%$ TAE agarose gels for agarose gel electrophoresis. Gels were run overnight at $40 \mathrm{~V}$ and $4{ }^{\circ} \mathrm{C}$, stained with ethidium bromide, and imaged using a c300 imager (Azure Biosystems). Approximate band sizes were calculated using GelAnalyzer software (GelAnalyzer 19.1). All CRE and ESBL-producing E. coli were subjected to plasmid replicon typing for the detection of 18 common E. coli incompatibility groups (IncB/O, FIC, A/C, P, T, K/B, W, FIIA, FIA, FIB, Y, I1, Frep, X, HI1, N, HI2, and $\mathrm{L} / \mathrm{M})$ via multiplex PCR [34].

\subsection{PCR Screenings for ExPEC}

PCRs were performed to identify the common E. coli phylogenetic groups (A, B1, B2, and D) and the presence of virulence factors associated with ExPEC plasmids ( $c v a C$, iroN, iss, and iutA) (Table S1).

\subsection{AMR Transfer Assays}

To assess horizontal gene transfer of plasmids carrying AMR genes by our isolates, we selected ESBL-producing E. coli isolates from CC (IA-EC-0010, IA-EC-0018) and CF (IA-EC0075, and IA-EC-0076) as donors, and avian pathogenic E. coli [APEC] $\chi 7122$, its plasmid cured derivative $\chi 7368, E$. coli $\mathrm{K}-12$ strain $\chi 6092$, E. coli K-12 strain MG1655 spontaneous 
nalidixic acid resistant mutant, and human commensal E. coli HS-4 spontaneous rifampicin mutant as recipients (Table 1). Strains were streaked onto MacConkey agar containing $4 \mathrm{mg} / \mathrm{L}$ cefotaxime (ESBL donors), $30 \mathrm{mg} / \mathrm{L}$ nalidixic acid ( $\chi 7122, \chi 7368$, and MG1655), $100 \mathrm{mg} / \mathrm{L}$ rifampicin (HS-4), and $15 \mathrm{mg} / \mathrm{L}$ tetracycline ( $\chi 6092)$. Single colonies were then suspended in $3 \mathrm{~mL}$ of LB broth supplemented with appropriate antibiotics for either the donor or recipient and shaken overnight at $37^{\circ} \mathrm{C}$. The overnight cultures were converted to OD600 1.0 with LB broth $(0.1 \%$ glucose $)$ and pelleted by centrifugation at $10,000 \times g$ for $10 \mathrm{~min}$. Donor and recipient pellets were resuspended with fresh LB, mixed in a 1:1 ratio, and incubated overnight at $37^{\circ} \mathrm{C}$. The following day, conjugation mixtures were serially diluted and plated on MacConkey agar with $4 \mathrm{mg} / \mathrm{L}$ cefotaxime (donor), $30 \mathrm{mg} / \mathrm{L}$ nalidixic acid ( $\chi 7122$ and $\chi 7368), 100 \mathrm{mg} / \mathrm{L}$ rifampicin (HS-4), or $15 \mathrm{mg} / \mathrm{L}$ tetracycline ( $\chi 6092$ ), and $4 \mathrm{mg} / \mathrm{L}$ cefotaxime, $30 \mathrm{mg} / \mathrm{L}$ nalidixic acid, $100 \mathrm{mg} / \mathrm{L}$ rifampicin, or $15 \mathrm{mg} / \mathrm{L}$ tetracycline (transconjugants). Transconjugants were then subjected to confirmation via plasmid gel profiling and PCR replicon typing.

Table 1. Relevant characteristics of donor and recipient strains.

\begin{tabular}{|c|c|c|c|}
\hline E. coli Strain & Notable Characteristics & $\begin{array}{l}\text { Selected Plasmidic } \\
\text { Virulence Factors }\end{array}$ & Source \\
\hline \multicolumn{4}{|l|}{ Recipients } \\
\hline \multirow[t]{2}{*}{$\chi 7122$} & APEC O78:K80:H9, nal ${ }^{\mathrm{R}}, \mathrm{str}^{\mathrm{R}}, \mathrm{lac}^{+}$ & $c v a C$, iss, iut $A$, iroN & [35] \\
\hline & Plasmids-cured $\chi 7122: \Delta$ pChi7122-1 & & \\
\hline \multirow[t]{2}{*}{$\chi 7368$} & $\Delta$ pChi7122-2 & - & {$[33]$} \\
\hline & $\Delta$ pChi7122-3, nal $^{\mathrm{R}}$, lac $^{+}$ & & \\
\hline$\chi 6092$ & E. coli $\mathrm{K}-12$, tet ${ }^{\mathrm{R}}$, $\mathrm{lac}^{-}$ & - & [36] \\
\hline MG1655 & E. coli $\mathrm{K}-12, \mathrm{nal}^{\mathrm{R}}$, $\mathrm{lac}^{+}$ & - & {$[37]$} \\
\hline HS-4 & Human commensal E. coli, rif $^{\mathrm{R}}, \mathrm{lac}^{-}$ & - & [38] \\
\hline \multicolumn{4}{|l|}{ Donor } \\
\hline IA-EC-0010 (CC) & $\mathrm{Lac}^{+}, \mathrm{ctx}^{\mathrm{R}}, \mathrm{caz}^{\mathrm{R}}, \mathrm{col}^{\mathrm{R}}$ & iut $A$ & This Study \\
\hline IA-EC-0018 (CC) & $\mathrm{Lac}^{+}, \mathrm{ctx}^{\mathrm{R}}, \mathrm{caz}^{\mathrm{col}} \mathrm{col}^{\mathrm{R}}$ & iss, iut $A$ & This Study \\
\hline IA-EC-0075 (CF) & $\mathrm{Lac}^{+}, \mathrm{ctx}^{\mathrm{R}}, \mathrm{caz}^{\mathrm{R}}$ & iutA & This Study \\
\hline IA-EC-0076 (CF) & $\mathrm{Lac}^{+}, \mathrm{ctx}^{\mathrm{R}}$ & iut $A$ & This Study \\
\hline \multicolumn{4}{|l|}{ Transconjugants } \\
\hline $\begin{array}{l}\begin{array}{l}\chi 7122 \\
\text { (pIA-EC-0010-2) }\end{array}\end{array}$ & $\mathrm{nal}^{\mathrm{R}}, \operatorname{str}^{\mathrm{R}}, \mathrm{ctx}^{\mathrm{R}}, \mathrm{caz}^{\mathrm{R}} \mathrm{lac}^{+}$, pIA-EC-0010-2 (Donor IA-EC-0010) & $c v a C$, iss, iut $A$, iroN & This Study \\
\hline $\begin{aligned} & \chi 7368 \\
&(\text { pIA-EC-0010-2) }\end{aligned}$ & $\mathrm{nal}^{\mathrm{R}}, \mathrm{ctx}^{\mathrm{R}}, \mathrm{caz}^{\mathrm{R}}, \mathrm{lac}^{+}$, pIA-EC-0010-2 (Donor IA-EC-0010) & - & This Study \\
\hline 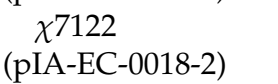 & $\mathrm{nal}^{\mathrm{R}}, \mathrm{str}^{\mathrm{R}}, \mathrm{ctx}^{\mathrm{R}}, \mathrm{caz}^{\mathrm{R}} \mathrm{lac}^{+}$, pIA-EC-0018-2 (Donor IA-EC-0018) & $c v a C$, iss, iut $A$, iroN & This Study \\
\hline $\begin{aligned} & \chi 7368 \\
&(\text { pIA-EC-0018-2) }\end{aligned}$ & $\mathrm{nal}^{\mathrm{R}}, \mathrm{ctx}^{\mathrm{R}}, \mathrm{caz}^{\mathrm{R}}, \mathrm{lac}^{+}$, pIA-EC-0018-2 (Donor IA-EC-0018) & - & This Study \\
\hline $\begin{array}{l}\chi 6092 \\
(\text { pIA-EC-0018-2) }\end{array}$ & tet $^{\mathrm{R}}, \mathrm{ctx}^{\mathrm{R}}, \mathrm{caz}^{\mathrm{R}}, \mathrm{lac}^{-}$, pIA-EC-0018-2 (Donor $\chi 7122$ (pIA-EC-0018-2) & - & This Study \\
\hline
\end{tabular}

\subsection{Statistics}

Prism software version 6.0 (GraphPad, San Diego, CA, USA) was used to calculate significance for all statistical analyses. One-way ANOVA followed by Turkey's test for multiple comparisons of means was used to compare differences between groups. $p$ values $<0.05$ were considered significant.

\section{Results}

\subsection{Widespread Antibiotic Resistance Detected in Poultry Fecal Isolates}

The breakdown of the total numbers of CRE, ESBL-producing E. coli and Acinetobacter, and CRA can be found in Table 2. Colistin resistant bacteria were detected, whereas 
ESBL-producing E. coli and Acinetobacter isolates were not detected until after enrichment. Colistin resistance was widely observed in bacteria from both $\mathrm{CC}$ and $\mathrm{CF}$ environments on CHROMagar COL-APSE ${ }^{\mathrm{TM}}$ plates (Figure 2). There were no significant differences $(p>0.05)$ in colistin-resistant bacteria abundances between the three laying periods within either environment. Of the total colonies that were resistant to colistin, 3.56\% in CC and $0.69 \%$ in CF were identified as CRE (Table 2). A total of $52 \mathrm{CRE}$ were isolated from CC and 48 from CF for future experiments. A total of $29(60 \%)$ CRE in CC and $27(47 \%)$ CRE in CF were shown to be resistant to colistin at concentrations up to $64 \mathrm{mg} / \mathrm{L}$ (Table S3). Using CHROMagar Orientation $^{\mathrm{TM}}$ plates post-enrichment, ESBL-production was relatively uncommon in both $\mathrm{CC}$ and $\mathrm{CF}$ isolates regardless of laying period. Of ESBL-producing isolates in the CC environment, $48 \%$ were identified as E. coli and 31\% were identified as Acinetobacter spp. (Table 2). Of the ESBL-producing isolates from the CF environment, 3\% were identified as E. coli and no Acinetobacter isolates were identified. Using CHROMagar SuperCARBA ${ }^{\mathrm{TM}}$ plates post-enrichment, carbapenem-resistant bacteria were solely identified in the CF environment. Of these isolates, $13 \%$ were identified as Acinetobacter. Importantly, the CRA isolates were shown to be resistant to both colistin and $\beta$-lactams, and were found in feces from CF hens in peak and late lay periods. All ESBL-producing E. coli and CRA were used for further experimentation. The minimum inhibitory concentration (MIC) of all CRE, ESBL-producing E. coli, and Acinetobacter to colistin, cefotaxime, and ceftazidime are listed in Supplementary Table S3.

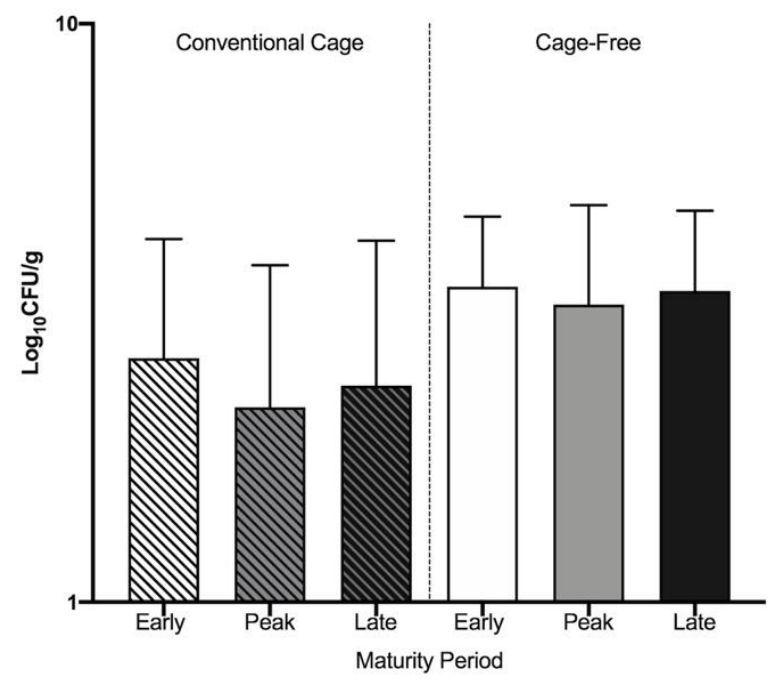

Figure 2. Prevalence of colistin-resistant bacteria in CC and CF. Total colistin-resistant bacteria were counted and $\log _{10} \mathrm{CFU} / \mathrm{g}$ were calculated for each lay period in both environments.

Table 2. Antimicrobial resistant bacteria detected in CC and CF Environments.

\begin{tabular}{|c|c|c|c|c|c|c|c|c|}
\hline \multirow{3}{*}{ Environment } & \multirow{3}{*}{ Lay Period } & \multicolumn{7}{|c|}{ Positively Identified Antibiotic Resistant Isolates } \\
\hline & & \multicolumn{2}{|c|}{ Pre-Enrichment } & \multicolumn{5}{|c|}{ Post-Enrichment } \\
\hline & & $\begin{array}{c}\text { Total } \\
\text { Colistin } \\
\text { (CFU/g) }\end{array}$ & $\begin{array}{c}\text { CRE } \\
\text { CFU/g (\% Total) }\end{array}$ & $\begin{array}{c}\text { Total } \\
\beta-\text { Lactam } \\
\text { (CFU/g) }\end{array}$ & $\begin{array}{c}\beta \text {-Lactam }{ }^{\mathrm{R}} \\
\text { E. coli CFU/g } \\
(\% \text { Total })\end{array}$ & $\begin{array}{c}\beta \text {-Lactam }{ }^{\mathrm{R}} \\
\text { Acinetobacter } \\
\text { CFU/g(\% Total) }\end{array}$ & $\begin{array}{c}\text { Total } \\
\text { CarbaR } \\
\text { (CFU/g) }\end{array}$ & $\underset{(\% \text { Total })}{\text { CRA CFU/g }}$ \\
\hline \multirow{3}{*}{$\mathrm{CC}$} & Early & $3.7 \times 10^{3}$ & $2 \times 10^{2}(5.57)$ & 41.7 & $41.7(100)$ & 0 & 0 & $0(0)$ \\
\hline & Peak & $1.9 \times 10^{3}$ & $1 \times 10^{2}(6.21)$ & 55.6 & $0(0)$ & $41.5(76.4)$ & 0 & $0(0)$ \\
\hline & Late & $7 \times 10^{3}$ & $1 \times 10^{2}(1.67)$ & $5.610^{2}$ & $0(0)$ & $13.3(36.2)$ & 0 & $0(0)$ \\
\hline \multirow{3}{*}{$\mathrm{CF}$} & Early & $2 \times 10^{4}$ & $1 \times 10^{2}(0.52)$ & $1.710^{2}$ & $17.9(10.5)$ & $0(0)$ & 50.5 & $0(0)$ \\
\hline & Peak & $2 \times 10^{4}$ & $1 \times 10^{2}(0.57)$ & $210^{2}$ & $0(0)$ & $0(0)$ & $1.3 \times 10^{2}$ & $22.5(16.7)$ \\
\hline & Late & $1 \times 10^{4}$ & $1.5 \times 10^{2}(1.19)$ & $1.510^{2}$ & $0(0)$ & $0(0)$ & $4 \times 10^{2}$ & $25.9(6.3)$ \\
\hline
\end{tabular}

Notes: $\mathrm{R}$, resistance; $\mathrm{CC}$, conventional cage; $\mathrm{CF}$, cage-free; $\mathrm{CFU}$, colony forming unit; $\mathrm{CRE}$, colistin resistant $E$. coli; Carba, carbapenem; CRA, carbapenem resistant Acinetobacter. 
Antibiotic resistance profiles for all CC and CF CRE, ESBL-producing E. coli, and Acinetobacter isolates are detailed in Figures 3 and 4, respectively. Tetracycline resistance was widely distributed in 45 (69\%) and 31 (56\%) of AMR bacteria in CC and CF, respectively. A total of $20 \mathrm{CC}$ and $13 \mathrm{CF}$ E. coli isolates were MDR against a combination of three or more antibiotics. CC and CF Acinetobacter were shown to be MDR as they were resistant to all antibiotics tested. CC Acinetobacter were not able to grow on CHROMagar SuperCARBA ${ }^{\mathrm{TM}}$ media like their CF counterparts (Figures 3 and 4). Using PCR to identify AMR genes corresponding to resistance mechanisms in these isolates, we found no isolates carrying any of the mor genes tested. Additionally, all ESBL-producing CC and CF E. coli carried the $b l a_{C M Y}$ gene, which encodes the Class $C \beta$-lactamase AmpC (Figure 5). Furthermore, only CC AmpC-producing E. coli carried the bla $a_{T E M}$ gene, which encodes the Class A ESBL TEM. The MDR Acinetobacter from CC also carried the bla ${ }_{C M} Y$ gene. However, CRA isolates were tested negative for the $\beta$-lactamase and carbapenemase-expressing genes tested in this study.

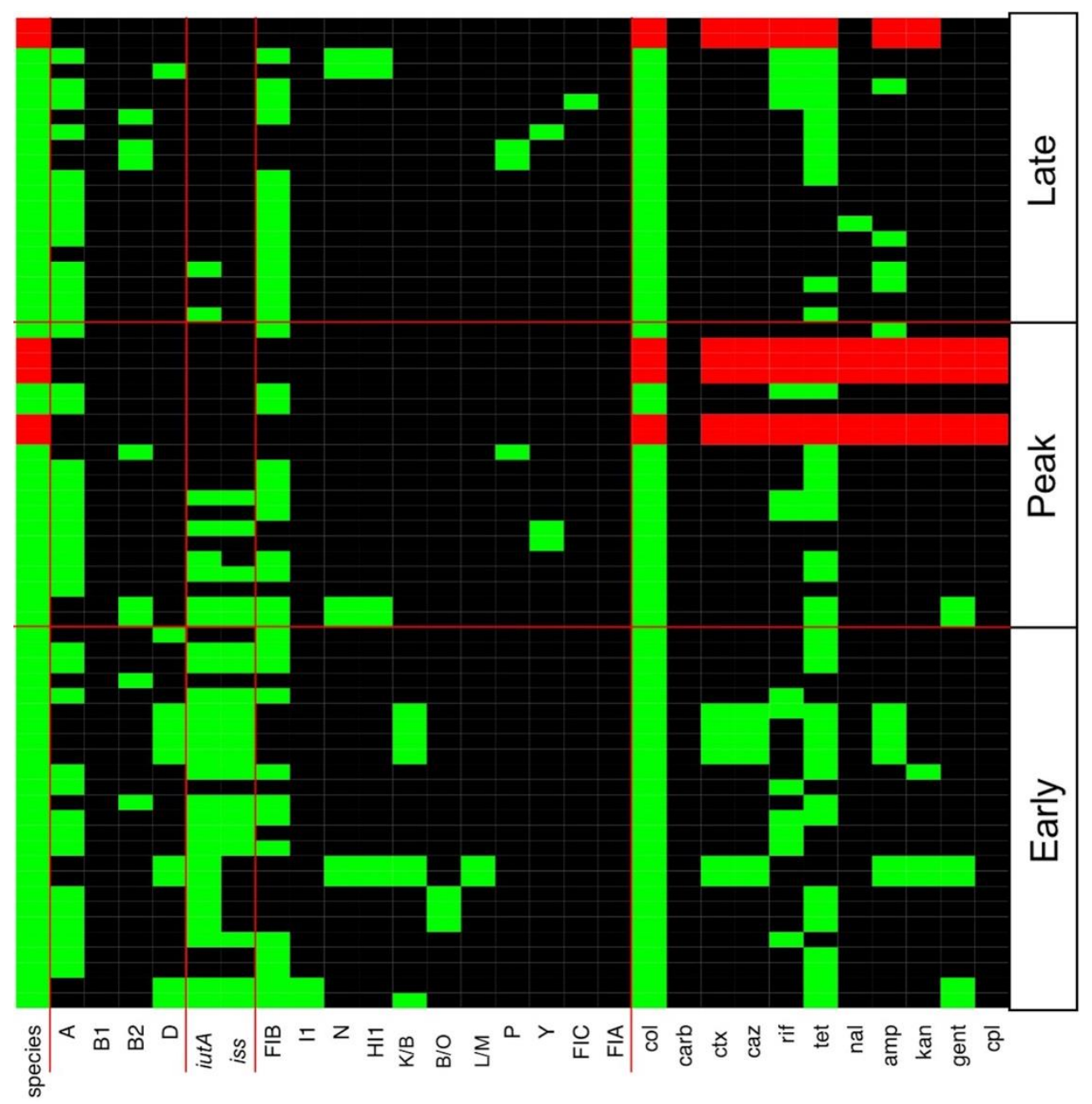

Figure 3. Heatmap of genes and phenotypes detected in conventional cage antibiotic resistant isolates. All positive E. coli results are shown in the heatmap as green. All positive Acinetobacter spp. are shown as red. Negative results are shown in black in the heatmap. Col, colistin; carb, carbapenem; ctx, cefotaxime; caz, ceftazidime; rif, rifampicin; tet, tetracycline; nal, nalidixic acid; amp, ampicillin; kan, kanamycin; gent, gentamicin; cpl, chloramphenicol. 


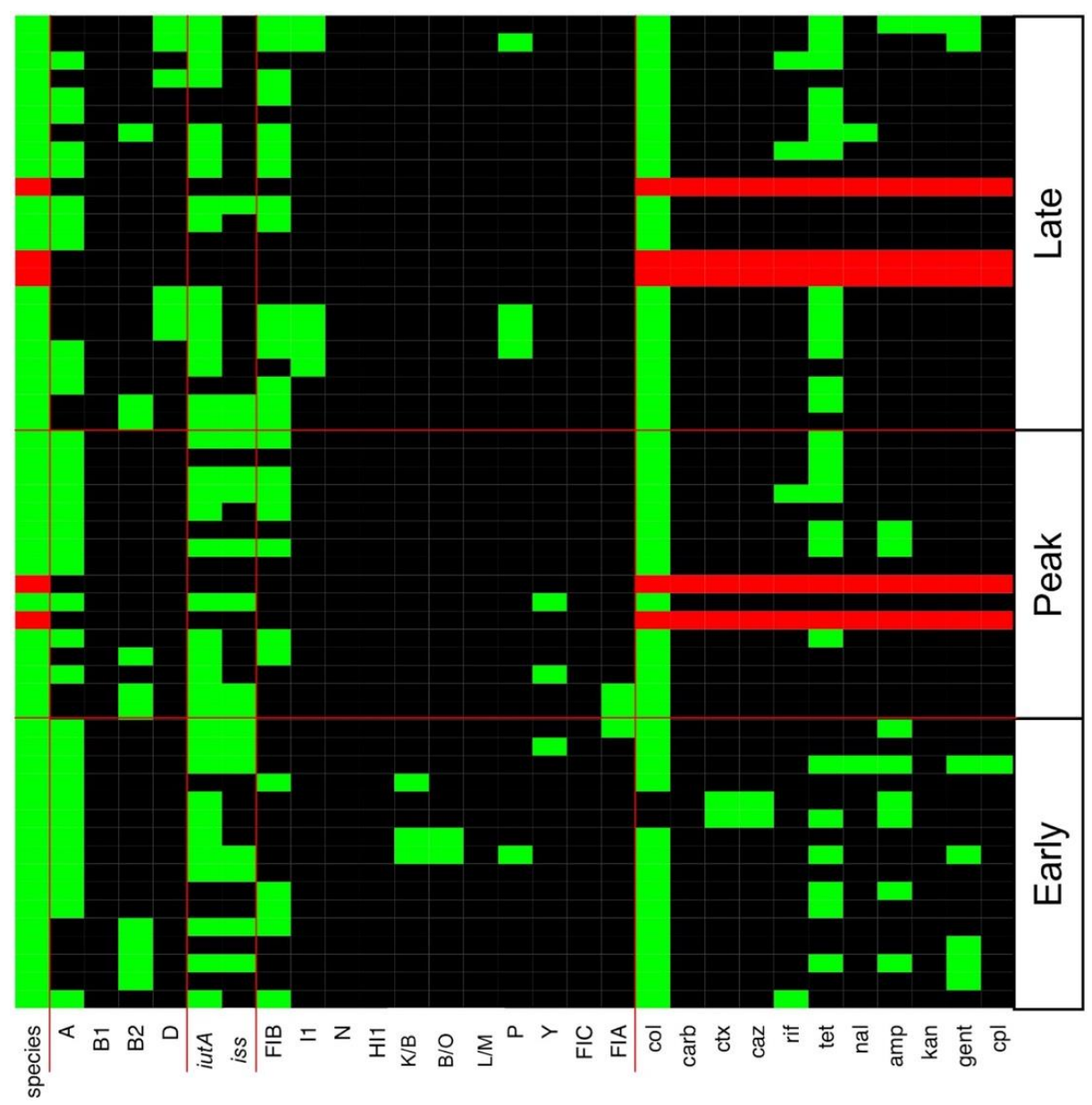

Figure 4. Heatmap of genes and phenotypes detected in cage-free antibiotic resistant isolates. All positive E. coli results are shown in the heatmap as green. All positive Acinetobacter spp. are shown as red. Negative results are shown in black in the heatmap. Col, colistin; carb, carbapenem; ctx, cefotaxime; caz, ceftazidime; rif, rifampicin; tet, tetracycline; nal, nalidixic acid; amp, ampicillin; kan, kanamycin; gent, gentamicin; cpl, chloramphenicol.

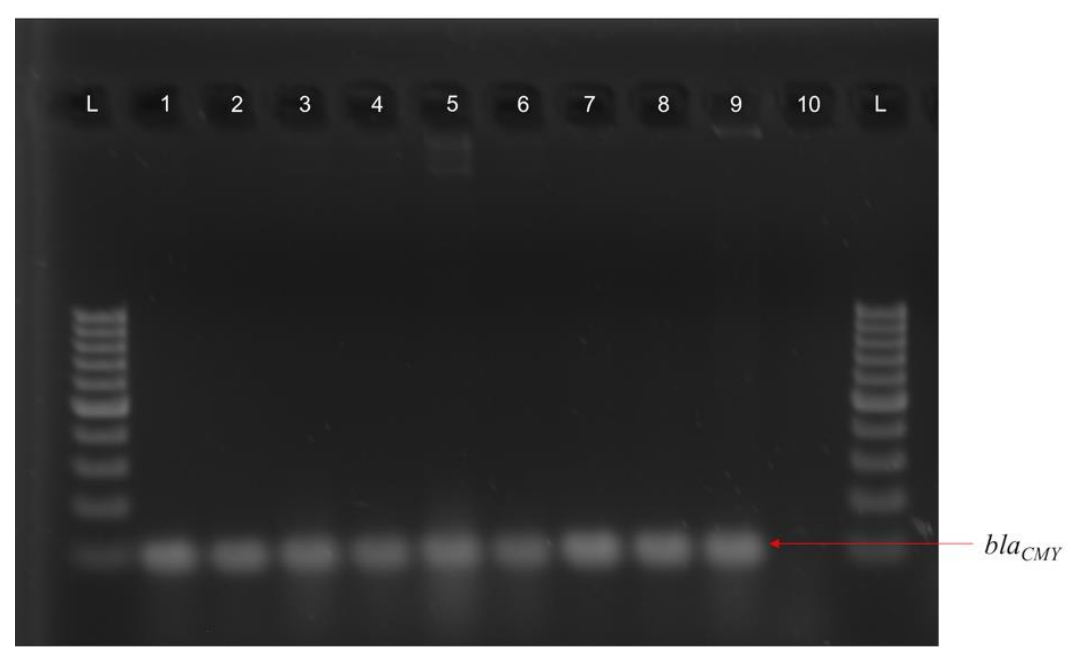

Figure 5. PCR for $b l a_{C M Y}$ in conventional cage and cage-free E. coli isolates. (L) $100 \mathrm{bp}$ ladder, (1) IA-EC-0010; (2) IA-EC-0011; (3) IA-EC-0018; (4) IA-EC-0019; (5) IA-EC-0020; (6) IA-EC-0021; (7) IA-EC-0075; (8) IA-EC-0076; (9) $\chi 7122$ (pIA-EC-0018) transconjugant; (10) $\chi 7122$ negative control. 


\subsection{Multiple Plasmid Types Found in AMR E. coli Isolates}

AMR E. coli isolates from CC and CF environments contained a variety of plasmids, ranging in size from $6 \mathrm{~kb}$ to $150 \mathrm{~kb}$ (Figure 6). However, we did not successfully extract plasmids from Acinetobacter isolates under any conditions.

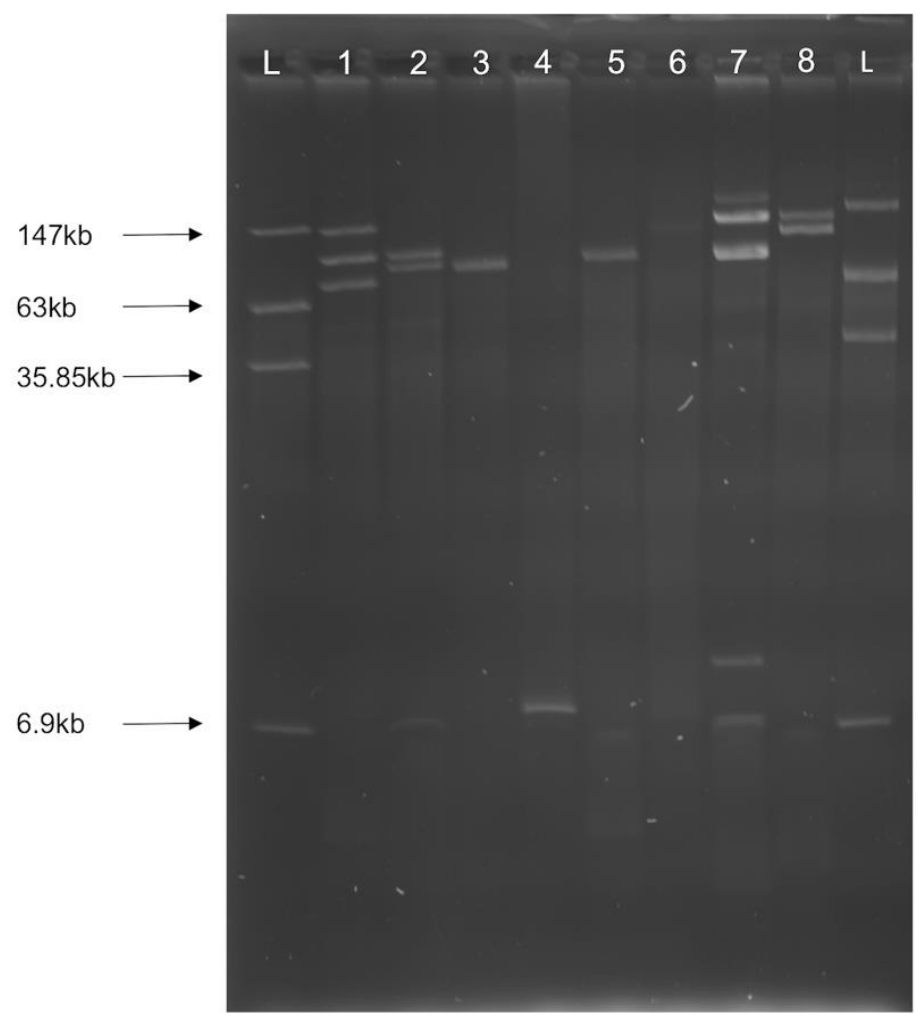

Figure 6. Plasmid profiles of representative AMR E. coli isolates. (L) Ladder E. coli 39R681; (1) IA-EC0002; (2) IA-EC-0024; (3) IA-EC-0030; (4) IA-EC-0035; (5) IA-EC-0052; (6), IA-EC-0060; (7) IA-EC-0010; (8) IA-EC-0073. Plasmid size was approximated using GelAnalyzer software.

Multiple incompatibility types, including I1, N, HI1, B/O, L/M, P, Y, FIA, FIB, and FIC, were found in E. coli isolates across all laying periods in both environments (Figures 3 and 4). IncFIB plasmids were detected in $38(58 \%)$ and $27(49 \%)$ of CC and CF AMR E. coli respectively (Figures 3 and 4). Furthermore, ESBL-producing E. coli from the CC environment all carried similar plasmids identified as IncK/B plasmids (Figure 3). However, ESBL-producing E. coli from CF did not yield any identified plasmids or replicon types (Figure 4). Replicon types IncA/C, FIIA, T, Frep, X, W, and HI2 were not detected in any isolates in this study.

3.3. Various ExPEC Phylogenetic Groups and Virulence Markers Genes Identified in AMR E. coli Isolates

Using PCR to predict virulence potential of AMR E. coli isolates, we found the ExPEC virulence factors iut $A$ and iss to be widespread in CC (Figure 3) and CF (Figure 4) AMR E. coli. A total of $28(48 \%)$ and 20 (34\%) of CC AMR E. coli carried iutA and iss, respectively. Similarly, a total of $38(69 \%)$ and 17 (31\%) of CF AMR E. coli carried iutA and iss, respectively. Furthermore, E. coli phylogenetic typing yielded both B2 and D groups known for their virulence and relation to ExPEC (Figures 3 and 4) [39]. Specifically, 8 (14\%) AMR E. coli were identified as B2 and $10(17 \%)$ as D in the CC environment. Similarly, $12(24 \%)$ AMR E. coli were identified as B2 and $4(8 \%)$ as D in the CF environment. 


\section{4. bla ${ }_{C M Y}$ Can Be Exchanged between Virulent and Non-Virulent E. coli through an IncK/B Plasmid}

Using in vitro conjugation assays to uncover a mechanism for $\beta$-lactam resistance dissemination, ESBL-producing E. coli (IA-EC-0010 and IA-EC-0018) isolates from CC were able to transfer the resistance of both cefotaxime and ceftazidime to both APEC strain $\chi 7122$ and its plasmid-cured derivative $\chi 7368$, but not to E. coli K-12 strain $\chi 6092$, MG1655, or human commensal HS-4. The AMR transfer was linked with the consistent transfer of a large $106 \mathrm{~kb}$ IncK/B plasmid (pIA-EC-0018-2) carrying the $b a_{C M Y}$ gene (Figure 5). However, using $\chi 7122$ (pIA-EC-0018-2) transconjugants from the previous assay as donors resulted in successful transfer of this large plasmid to $\chi 6092$ (Figure 7). The virulence markers iss and iut $A$ that were observed in the donor strains were not transferred to the recipients. $C F$ E. coli were unable to transfer $b l a_{C M Y}$ under any conditions tested in this study.

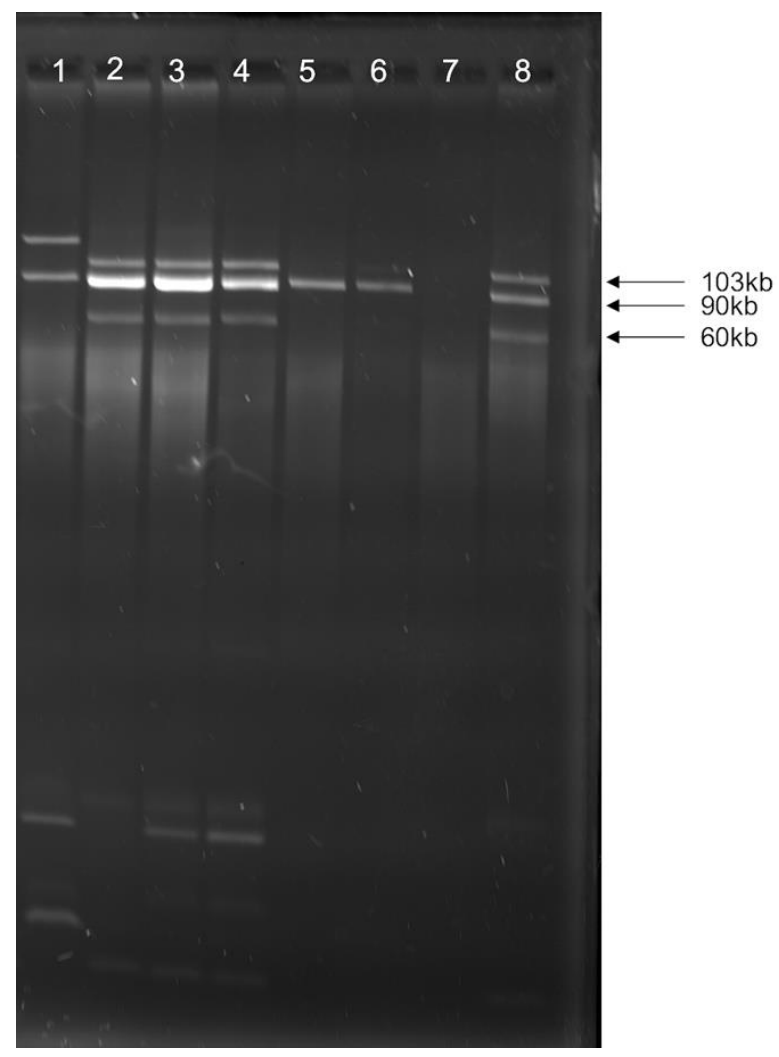

Figure 7. Plasmid profiles of donor, recipient, and transconjugant strains. (1) Donor IA-EC-0018; (2-4) transconjugant $\chi 7122$ (pIA-EC-0018-2); (5-6) trans-conjugant $\chi 6092$ (pIA-EC-0018-2); (7) recipient $\chi 6092 ;(8)$ recipient $\chi 7122$.

\section{Discussion}

Commensal bacteria like Enterobacteriaceae and pathogens isolated from the chicken GIT are commonly resistant to multiple antibiotics [40]. Commonly, E. coli isolates sourced from chickens have shown resistance to tetracycline, chloramphenicol, ampicillin, and streptomycin due to the indiscriminate use of these antibiotics as growth promoters in poultry production $[41,42]$. Concurrent with these studies, our results show the extensive antibiotic resistance patterns associated with E. coli from both CC and CF farms in all maturity stages. Furthermore, the amount of CRE isolated from each maturity stage did not differ. Alarmingly, numerous CRE isolates from both CC and CF showed MDR to multiple antibiotics tested. Recent research has shown that the maturity of layer hens plays a significant role in the diversity of the ceca microbiota [26]. Although the detection of CRE is increasing in the poultry environment $[15,43,44]$, there is little information on how maturity can impact the presence of these AMR bacteria. Factors such as disease and antibiotic 
intervention can drive the emergence of AMR bacteria in the poultry environment [45]. As the presence of MDR bacteria from chickens increases, the detection of specific resistance genes illustrates a relationship between resistant bacteria and the spread of resistance mechanisms. Future studies should investigate the role that the environment and possible intervention strategies that can limit the emergence of colistin resistant bacteria.

Our study highlights the importance of detection methods for colistin resistant bacteria using media like CHROMagar COL-APSE ${ }^{\mathrm{TM}}$. Notably, CHROMagar COL-APSE ${ }^{\mathrm{TM}}$ adheres to the European Committee on Antimicrobial Susceptibility Testing (EUCAST). The EUCAST breakpoint for colistin resistance is strictly set at $2 \mathrm{mg} / \mathrm{L}$, whereas CLSI resistance cutoff in the United States is $4 \mathrm{mg} / \mathrm{L}$. All isolates that were initially selected from CHROMagar COL-APSETM were identified as resistant on MHA according to the EUCAST breakpoint of $2 \mathrm{mg} / \mathrm{L}$ [46]. The number of isolates initially selected from the CHROMagar COL-APSE ${ }^{\mathrm{TM}}$ media was greatly reduced after screening using MHA with $4 \mathrm{mg} / \mathrm{L}$ colistin. Using both CHROMagar COL-APSE ${ }^{\mathrm{TM}}$ media and further selection using CLSI guidelines can be useful for accurate detection of resistant isolates. Although use of CHROMagar COL-APSETM and further confirmation with either CLSI or EUCAST guidelines can identify multiple resistant bacteria, these methods do not accurately detect the presence of $\mathrm{mcr}$ genes [47]. PCR investigation of all confirmed colistin resistant bacteria should be performed to confirm the presence of the emerging $\mathrm{mor}$ genes.

The emergence of $\mathrm{mcr}$ genes in multiple settings have become an increasing global threat $[14,48]$. Notably, the principle $m c r-1$ gene has been reported in over 40 countries to date [49]. None of the $m c r$ genes tested in our study ( $m c r-1, m c r-2, m c r-3, m c r-4$, and $m c r-5)$ were detected in any of our CRE isolates. Although our isolates did not carry the $m c r$ genes that are often spread through conjugative plasmids [50], our study highlights the ability of AMR E. coli from chickens to exhibit spontaneous resistance to colistin. There are several mechanisms that can contribute to the ability of bacteria to become spontaneously resistant to colistin. For instance, the most common resistance strategy involves the modification of the bacterial outer membrane through alteration in the lipopolysaccharide (LPS) and reduction in its negative charge as this negative charge is the target of colistin [51]. Furthermore, overexpression of efflux-pump systems and overproduction of capsule polysaccharides can enhance the resistance to colistin in Enterobacteriaceae [52,53]. The possibility of threatening AMR bacteria like ESBL-producing E. coli and MDR Acinetobacter to exhibit resistance to colistin spontaneously is concerning because of colistin's use as a last resort antibiotic [54].

As evidenced in this study, the detection of ESBL-producing E. coli and MDR Acinetobacter can be detected in the poultry environment. In order to understand the genetic attributes that contributed to the resistance of these isolates, we investigated multiple $\beta$ lactamase and carbapenemase producing genes in both groups. Specifically, we attempted to detect the $b l a_{T E M}, b l a_{S H V}, b l a_{C T X-M}$, and $b l a_{C M Y} \beta$-lactamase genes as these $\beta$-lactamases are the most commonly identified [55]. Furthermore, we attempted to detect carbapenemase genes $b l a_{O X A}, b l a_{K P C}$, and bla $a_{V I M}$ that are commonly found in CRA [56-58]. As none of the $\beta$-lactamase and carbapenemase genes were detected in the CRA isolates, other resistance mechanisms are likely responsible for the resistance. Carbapenem resistance in Acinetobacter can be mediated by reduced drug permeability through porin loss or modification and the overexpression of efflux pump [59,60]. Interestingly, we successfully identified the AmpC Class C $\beta$-lactamase encoding $b l a_{C M Y}$ gene in only the early lay period of both $\mathrm{CC}$ and $\mathrm{CF}$ environments. bla $a_{\mathrm{CM} Y}$ has been increasingly reported in chickens as a source for the spread of AmpC to both human and avian pathogenic bacteria [61,62]. Although $b l a_{C M Y}$ is not classified as an extended-spectrum $\beta$-lactamase, the AmpC $\beta$-lactamase is resistant to otherwise useful $\beta$-lactamase inhibitors like clavulanic acid that is often paired with antibiotics, like ceftazidime, to limit the effects of $\beta$-lactamases $[63,64]$. Strikingly, in our study the ESBL gene $b l a_{T E M}$ was detected in all cephalosporin resistant CC E. coli, illustrating the ability of AMR E. coli to harbor multiple $\beta$-lactamase producing genes.

To evaluate whether CRE and ESBL-producing E. coli detected in this study can be pathogenic, we tested our isolates using E. coli phylogenetic typing, a common technique 
utilized to sort E. coli isolates into groups that differ in ecological niches, life-history characteristics, and propensity to cause disease [65]. Namely, four main E. coli phylotypes (A, B1, B2, and D) are extensively used for classification [66-68]. We identified A, B2, and $\mathrm{D}$ groups in all maturity stages in both environments. Historically, phylogenetic group A is more commonly associated with commensal E. coli, whereas phylogenetic groups B2 and $D$ are associated with virulent ExPEC infections $[69,70]$. For instance, phylogenetic groups B2 and D have been associated with E. coli isolates that cause urinary tract infections (UTI) and show increased presence of virulence [71] factors associated with UTI when compared to the B1 and A phylogenetic groups.

Additionally, because of their plasmidic location, we attempted to detect four ExPECassociated virulence factors $(c v a C$, iroN, iss, and iut A) among our isolates [33]. $c v a C$ and iroN were not identified in any of our isolates. However, there was wide distribution of both iss and iut $A$ in isolated from both environments. Interestingly, the late lay period of the $C C$ isolates exhibited markedly less iss and iut $A$ than the early and peak lay periods. Encoding the receptor for the siderophore aerobactin, iut $A$ is an important factor in urinary pathogenic $E$. coli (UPEC) infections that allow the bacteria to competitively acquire iro $N$ that would otherwise be acquired by the host [72]. Furthermore, the iss virulence factor encodes a specific outer membrane protein that increases serum survival for ExPEC during extraintestinal infection [73]. In addition to their role in the pathogenesis, these virulence factors could confer a competitive advantage to isolates that express them compared to their counterparts in the GIT.

The ability for E. coli to spread AMR genes through plasmids via HGT plays a significant role on the distribution of resistance in different bacteria. Several factors play a role in the ability of plasmids to be transferred between bacteria. For instance, incompatibility restriction, host genetics, and strain-specific factors can influence the transfer of plasmids $[38,74,75]$. In this study, we investigated a total of 18 plasmid incompatibility groups in all E. coli isolates. We were able to identify several isolates that carry IncN, P, HI1, and I1 incompatibility groups that have been shown to be associated with a broad-host range [76-78]. Interestingly, in our study, all ESBL-producing E. coli in the CC environment carried IncK/B type plasmids. Due to their multiple plasmids visualized in plasmid extraction, and presence of the common IncK/B plasmids, the CC ESBL-producing E. coli were selected for conjugation assays. CF E. coli that carried the bla $a_{C M Y}$ gene did not yield any of the plasmid replicon types investigated in this study, and conjugation was not observed under any conditions. Furthermore, CRA isolates did not yield any plasmid replicon types investigated in this study, and no plasmids were visualized using the method described or using IBI-Scientific (Dubuque, IA, USA) and Qiagen (Hilden, Germany) commercially available plasmid extraction kits. This suggests that the AMR genes of these isolates could be chromosomal rather than plasmidic.

In this study, we demonstrated the ability of the ESBL-producing E. coli from CC to transfer AmpC $\beta$-lactamase via a large $106 \mathrm{~kb}$ IncK/B plasmid (pAmpC) to a variety of hosts, including the APEC strain $\chi 7122$, its avirulent plasmid-cured derivative $\chi 7368$, and E. coli K-12 $\chi 6092$, indicating the ability of the plasmid to transfer to both virulent and non-virulent bacteria. Interestingly, numerous studies have highlighted the presence of pAmpC associated with both IncK plasmids and the poultry environment [79-82]. Although transfer of AMR genes and plasmidic virulence factors on the same plasmid has been shown [83,84], the ESBL-producing donors in our study did not transfer the virulence factors iss and iutA to the avirulent strains. This suggests that the plasmidic virulence factors are located on different plasmids than the $\mathrm{pAmpC}$ in the donor strains. Nonetheless, the presence of $\mathrm{pAmpC}$ in populations of MDR bacteria with the propensity to cause disease is concerning. Finally, increased detection of $\mathrm{pAmpC}$ can cause an eventual decline in the efficacy of cephalosporin antibiotics in both humans and poultry. 


\section{Conclusions}

Overall, this study identified wide-spread colistin-resistant E. coli and MDR E. coli in all three lay periods in CC and CF hens. AmpC $\beta$-lactamase mediated bla $C M Y$ was identified in E. coli and Acinetobacter of CC and E. coli of CF. Furthermore, MDR Acinetobacter were detected in peak and late lay periods of both $\mathrm{CC}$ and $\mathrm{CF}$, with $\mathrm{CF}$ isolates being also resistant to carbapenems. Finally, the AmpC $\beta$-lactamase mediated bla $C M Y$ was shown to be plasmidborne in the CC environment only. Future experimental studies will seek environmental and host factors that trigger dissemination of novel and threatening antibiotic resistant patterns to enable comparisons between CC and CF hens, as well as further sequencing of resistant isolates and transferable plasmids to understand the prevalent resistance genes in laying hens of different maturity stages.

Supplementary Materials: The following are available online at https:/ /www.mdpi.com/2076-2 607/9/1/141/s1. Table S1: PCR Primer Pairs Utilized in Study, Table S2: Some Strains Utilized in Study, Table S3: The Minimum Inhibitory Concentration (MIC) of the last resort antibiotics on the resistant isolates.

Author Contributions: Conceptualization, M.M.; methodology, J.M.J., G.J.A.R., L.C.O., and M.M.; validation, M.M.; formal analysis, J.M.J. and M.M.; investigation, J.M.J.; resources, M.M.; data curation, J.M.J.; writing — original draft preparation, J.M.J. and M.M.; writing—review and editing, J.M.J., G.J.A.R., L.C.O., and M.M.; visualization, J.M.J., G.J.A.R., and M.M.; supervision, M.M.; project administration, M.M.; funding acquisition, M.M. All authors have read and agreed to the published version of the manuscript.

Funding: This research was supported by Iowa State University Start-up funding and the United States Department of Agriculture (USDA) Hatch project IOW03902 to M.M. The funders played no role in study design, data collection, and interpretation, or the decision to submit the work for publication.

Conflicts of Interest: The authors declare that the research was conducted in the absence of any commercial or financial relationships that could be construed as potential conflict of interest.

\section{References}

1. Naylor, N.R.; Pouwels, K.B.; Hope, R.; Green, N.; Henderson, K.L.; Knight, G.M.; Atun, R.; Robotham, J.V.; Deeny, S.R. The Health and Cost Burden of Antibiotic Resistant and Susceptible Escherichia coli Bacteraemia in the English Hospital Setting: A National Retrospective Cohort Study. PLoS ONE 2019, 14, e221944. [CrossRef] [PubMed]

2. Economou, V.; Gousia, P. Agriculture and Food Animals as a Source of Antimicrobial-Resistant Bacteria. Infect. Drug Resist. 2015, 8, 49-61. [CrossRef] [PubMed]

3. Hegde, N.V.; Kariyawasam, S.; DebRoy, C. Comparison of Antimicrobial Resistant Genes in Chicken Gut Microbiome Grown on Organic and Conventional Diet. Vet. Anim. Sci. 2016, 1-2, 9-14. [CrossRef] [PubMed]

4. Wang, L.; Wang, J.; Wang, J.; Zhu, L.; Yang, L.; Yang, R. Distribution Characteristics of Antibiotic Resistant Bacteria and Genes in Fresh and Composted Manures of Livestock Farms. Sci. Total Environ. 2019, 695, 133781. [CrossRef]

5. Ghaffoori Kanaan, M.H.; Al-Shadeedi, S.M.J.; Al-Massody, A.J.; Ghasemian, A. Drug Resistance and Virulence Traits of Acinetobacter baumannii from Turkey and Chicken Raw Meat. Comp. Immunol. Microbiol. Infect. Dis. 2020, 70, 101451. [CrossRef]

6. Monte, D.F.; Mem, A.; Fernandes, M.R.; Cerdeira, L.; Esposito, F.; Galvão, J.A.; Lincopan, N.; Landgraf, M. Chicken Meat as a Reservoir of Colistin-Resistant Escherichia coli Strains Carrying Mcr-1 Genes in South America. Antimicrob. Agents Chemother. 2017, 61, 4. [CrossRef]

7. Vitas, A.I.; Naik, D.; Pérez-Etayo, L.; González, D. Increased Exposure to Extended-Spectrum $\beta$-Lactamase-Producing MultidrugResistant Enterobacteriaceae through the Consumption of Chicken and Sushi Products. Int. J. Food Microbiol. 2018, 269, 80-86. [CrossRef]

8. CDC. The Biggest Antibiotic-Resistant Threats in the U.S. Available online: https://www.cdc.gov/drugresistance/biggestthreats.html (accessed on 22 October 2019).

9. Mendelson, M.; Brink, A.; Gouws, J.; Mbelle, N.; Naidoo, V.; Pople, T.; Schellack, N.; van Vuuren, M.; Rees, H.; Banoo, S.; et al. The One Health Stewardship of Colistin as an Antibiotic of Last Resort for Human Health in South Africa. Lancet Infect. Dis. 2018, 18, e288-e294. [CrossRef]

10. FAO's Animal Production and Health Division: Meat \& Meat Products. Available online: http://www.fao.org/ag/againfo/ themes/en/meat/backgr_sources.html (accessed on 11 November 2020). 
11. Stecher, B.; Denzler, R.; Maier, L.; Bernet, F.; Sanders, M.J.; Pickard, D.J.; Barthel, M.; Westendorf, A.M.; Krogfelt, K.A.; Walker, A.W.; et al. Gut Inflammation Can Boost Horizontal Gene Transfer between Pathogenic and Commensal Enterobacteriaceae. Proc. Natl. Acad. Sci. USA 2012, 109, 1269-1274. [CrossRef]

12. Johnson, T.J.; Nolan, L.K. Pathogenomics of the Virulence Plasmids of Escherichia coli. Microbiol. Mol. Biol. Rev. 2009, 73, 750-774. [CrossRef]

13. Norman, A.; Hansen, L.H.; She, Q.; Sørensen, S.J. Nucleotide Sequence of POLA52: A Conjugative IncX1 Plasmid from Escherichia coli Which Enables Biofilm Formation and Multidrug Efflux. Plasmid 2008, 60, 59-74. [CrossRef] [PubMed]

14. Hassen, B.; Abbassi, M.S.; Ruiz-Ripa, L.; Mama, O.M.; Hassen, A.; Torres, C.; Hammami, S. High Prevalence of Mcr-1 Encoding Colistin Resistance and First Identification of BlaCTX-M-55 in ESBL/CMY-2-Producing Escherichia coli Isolated from Chicken Faeces and Retail Meat in Tunisia. Int. J. Food Microbiol. 2020, 318, 108478. [CrossRef] [PubMed]

15. Wu, C.; Wang, Y.; Shi, X.; Wang, S.; Ren, H.; Shen, Z.; Wang, Y.; Lin, J.; Wang, S. Rapid Rise of the ESBL and Mcr-1 Genes in Escherichia coli of Chicken Origin in China, 2008-2014. Emerg. Microbes Infect. 2018, 7, 1-10. [CrossRef] [PubMed]

16. Ballou, A.L.; Ali, R.A.; Mendoza, M.A.; Ellis, J.C.; Hassan, H.M.; Croom, W.J.; Koci, M.D. Development of the Chick Microbiome: How Early Exposure Influences Future Microbial Diversity. Front. Vet. Sci. 2016, 3. [CrossRef] [PubMed]

17. Card, R.M.; Cawthraw, S.A.; Nunez-Garcia, J.; Ellis, R.J.; Kay, G.; Pallen, M.J.; Woodward, M.J.; Anjum, M.F. An In Vitro Chicken Gut Model Demonstrates Transfer of a Multidrug Resistance Plasmid from Salmonella to Commensal Escherichia coli. mBio 2017, 8. [CrossRef] [PubMed]

18. Haberecht, S.; Bajagai, Y.S.; Moore, R.J.; Van, T.T.H.; Stanley, D. Poultry Feeds Carry Diverse Microbial Communities That Influence Chicken Intestinal Microbiota Colonisation and Maturation. AMB Express 2020, 10. [CrossRef]

19. Lupo, A.; Vogt, D.; Seiffert, S.N.; Endimiani, A.; Perreten, V. Antibiotic Resistance and Phylogenetic Characterization of Acinetobacter baumannii Strains Isolated from Commercial Raw Meat in Switzerland. J. Food Prot. 2014, 77, 1976-1981. [CrossRef] [PubMed]

20. Mellata, M. Human and Avian Extraintestinal Pathogenic Escherichia coli: Infections, Zoonotic Risks, and Antibiotic Resistance Trends. Foodborne Pathog. Dis. 2013, 10, 916-932. [CrossRef]

21. Mlynarcik, P.; Bardon, J.; Htoutou Sedlakova, M.; Prochazkova, P.; Kolar, M. Identification of Novel OXA-134-like $\beta$-Lactamases in Acinetobacter Lwoffii and Acinetobacter Schindleri Isolated from Chicken Litter. Biomed. Pap. Med. Fac. Univ. Palacky Olomouc. Czech Repub. 2019, 163, 141-146. [CrossRef]

22. Zilberberg, M.D.; Nathanson, B.H.; Sulham, K.; Fan, W.; Shorr, A.F. Multidrug Resistance, Inappropriate Empiric Therapy, and Hospital Mortality in Acinetobacter baumannii Pneumonia and Sepsis. Crit. Care 2016, 20. [CrossRef]

23. Manges, A.R.; Geum, H.M.; Guo, A.; Edens, T.J.; Fibke, C.D.; Pitout, J.D.D. Global Extraintestinal Pathogenic Escherichia coli (ExPEC) Lineages. Clin. Microbiol. Rev. 2019, 32, e00135-18,. [CrossRef] [PubMed]

24. Cui, Y.; Wang, Q.; Liu, S.; Sun, R.; Zhou, Y.; Li, Y. Age-Related Variations in Intestinal Microflora of Free-Range and Caged Hens. Front. Microbiol. 2017, 8. [CrossRef] [PubMed]

25. Gole, V.C.; Caraguel, C.G.B.; Sexton, M.; Fowler, C.; Chousalkar, K.K. Shedding of Salmonella in Single Age Caged Commercial Layer Flock at an Early Stage of Lay. Int. J. Food Microbiol. 2014, 189, 61-66. [CrossRef] [PubMed]

26. Van Goor, A.; Redweik, G.A.J.; Stromberg, Z.R.; Treadwell, C.G.; Xin, H.; Mellata, M. Microbiome and Biological Blood Marker Changes in Hens at Different Laying Stages in Conventional and Cage Free Housings. Poult. Sci. 2020, 99, 2362-2374. [CrossRef] [PubMed]

27. Yang, X. Moraxellaceae. In Encyclopedia of Food Microbiology; Elsevier: Lacombe, AB, Canada, 2014; pp. 826-833.

28. Gomes-Neto, J.C.; Mantz, S.; Held, K.; Sinha, R.; Segura Munoz, R.R.; Schmaltz, R.; Benson, A.K.; Walter, J.; Ramer-Tait, A.E. A Real-Time PCR Assay for Accurate Quantification of the Individual Members of the Altered Schaedler Flora Microbiota in Gnotobiotic Mice. J. Microbiol. Methods 2017, 135, 52-62. [CrossRef] [PubMed]

29. Fernando, D.M.; Khan, I.U.H.; Patidar, R.; Lapen, D.R.; Talbot, G.; Topp, E.; Kumar, A. Isolation and Characterization of Acinetobacter baumannii Recovered from Campylobacter Selective Medium. Front Microbiol. 2016, 7. [CrossRef]

30. CLSI Performance Standards for Antimicrobial Susceptibility Testing 2020; Clinical and Laboratory Standards Institute: Wayne, PA, USA, 2020.

31. Rebelo, A.R.; Bortolaia, V.; Kjeldgaard, J.S.; Pedersen, S.K.; Leekitcharoenphon, P.; Hansen, I.M.; Guerra, B.; Malorny, B.; Borowiak, M.; Hammerl, J.A.; et al. Multiplex PCR for Detection of Plasmid-Mediated Colistin Resistance Determinants, Mcr-1, Mcr-2, Mcr-3, Mcr-4 and Mcr-5 for Surveillance Purposes. Eurosurveillance 2018, 23, 17-00672. [CrossRef]

32. Singh, P.; Pfeifer, Y.; Mustapha, A. Multiplex Real-Time PCR Assay for the Detection of Extended-Spectrum $\beta$-Lactamase and Carbapenemase Genes Using Melting Curve Analysis. J. Microbiol. Methods 2016, 124, 72-78. [CrossRef]

33. Mellata, M.; Ameiss, K.; Mo, H.; Curtiss, R. Characterization of the Contribution to Virulence of Three Large Plasmids of Avian Pathogenic Escherichia coli X7122 (O78:K80:H9). IAI 2010, 78, 1528-1541. [CrossRef]

34. Johnson, T.J.; Wannemuehler, Y.M.; Johnson, S.J.; Logue, C.M.; White, D.G.; Doetkott, C.; Nolan, L.K. Plasmid Replicon Typing of Commensal and Pathogenic Escherichia coli Isolates. Appl. Environ. Microbiol. 2007, 73, 1976-1983. [CrossRef]

35. Brown, P.K.; Curtiss, R. Unique Chromosomal Regions Associated with Virulence of an Avian Pathogenic Escherichia coli Strain. Proc. Natl. Acad. Sci. USA 1996, 93, 11149-11154. [CrossRef] [PubMed]

36. Mellata, M.; Touchman, J.W.; Curtiss, R. Full Sequence and Comparative Analysis of the Plasmid PAPEC-1 of Avian Pathogenic E. coli X7122 (O78:K80:H9). PLoS ONE 2009, 4, e4232. [CrossRef] [PubMed] 
37. Stromberg, Z.R.; Van Goor, A.; Redweik, G.A.J.; Wymore Brand, M.J.; Wannemuehler, M.J.; Mellata, M. Pathogenic and NonPathogenic Escherichia coli Colonization and Host Inflammatory Response in a Defined Microbiota Mouse Model. Dis. Models Mech. 2018, 11, dmm035063. [CrossRef] [PubMed]

38. Ott, L.C.; Stromberg, Z.R.; Redweik, G.A.J.; Wannemuehler, M.J.; Mellata, M. Mouse Genetic Background Affects Transfer of an Antibiotic Resistance Plasmid in the Gastrointestinal Tract. mSphere 2020, 5. [CrossRef]

39. Nowrouzian, F.L.; Wold, A.E.; Adlerberth, I. Escherichia coli Strains Belonging to Phylogenetic Group B2 Have Superior Capacity to Persist in the Intestinal Microflora of Infants. J. Infect. Dis. 2005, 191, 1078-1083. [CrossRef]

40. Skarżyńska, M.; Leekitcharoenphon, P.; Hendriksen, R.S.; Aarestrup, F.M.; Wasyl, D. A Metagenomic Glimpse into the Gut of Wild and Domestic Animals: Quantification of Antimicrobial Resistance and More. PLoS ONE 2020, 15, e0242987. [CrossRef]

41. Al Azad, M.A.R.; Rahman, M.M.; Amin, R.; Begum, M.I.A.; Fries, R.; Husna, A.; Khairalla, A.S.; Badruzzaman, A.T.M.; El Zowalaty, M.E.; Lampang, K.N.; et al. Susceptibility and Multidrug Resistance Patterns of Escherichia coli Isolated from Cloacal Swabs of Live Broiler Chickens in Bangladesh. Pathogens 2019, 8, 118. [CrossRef]

42. Ievy, S.; Islam, M.S.; Sobur, M.A.; Talukder, M.; Rahman, M.B.; Khan, M.F.R.; Rahman, M.T. Molecular Detection of Avian Pathogenic Escherichia coli (APEC) for the First Time in Layer Farms in Bangladesh and Their Antibiotic Resistance Patterns. Microorganisms 2020, 8, 1021. [CrossRef]

43. Grami, R.; Mansour, W.; Mehri, W.; Bouallègue, O.; Boujaâfar, N.; Madec, J.-Y.; Haenni, M. Impact of Food Animal Trade on the Spread of mcr-1-Mediated Colistin Resistance, Tunisia, July 2015. Eurosurveillance 2016, 21. [CrossRef]

44. Wang, Y.; Zhang, R.; Li, J.; Wu, Z.; Yin, W.; Schwarz, S.; Tyrrell, J.M.; Zheng, Y.; Wang, S.; Shen, Z.; et al. Comprehensive Resistome Analysis Reveals the Prevalence of NDM and MCR-1 in Chinese Poultry Production. Nat. Microbiol. 2017, 2, 16260. [CrossRef]

45. Xiong, W.; Wang, Y.; Sun, Y.; Ma, L.; Zeng, Q.; Jiang, X.; Li, A.; Zeng, Z.; Zhang, T. Antibiotic-Mediated Changes in the Fecal Microbiome of Broiler Chickens Define the Incidence of Antibiotic Resistance Genes. Microbiome 2018, 6, 34. [CrossRef] [PubMed]

46. The European Committee of Antimicrobial Susceptibilitiy Testing Breakpoint Tables for Interpretation of MICs and Zone Diameters Version 10.0 2020; The European Committee of Antimicrobial Susceptibility Testing: Växjö, Sweden, 2020.

47. Thiry, D.; Berrah, A.; Evrard, J.; Duprez, J.-N.; Mainil, J.G.; Saulmont, M. Assessment of Two Selective Agar Media to Isolate Colistin-Resistant Bovine Escherichia coli: Correlation with Minimal Inhibitory Concentration and Presence of Mcr Genes. J. Microbiol. Methods 2019, 159, 174-178. [CrossRef] [PubMed]

48. Huang, X.; Yu, L.; Chen, X.; Zhi, C.; Yao, X.; Liu, Y.; Wu, S.; Guo, Z.; Yi, L.; Zeng, Z.; et al. High Prevalence of Colistin Resistance and Mcr-1 Gene in Escherichia coli Isolated from Food Animals in China. Front. Microbiol. 2017, 8. [CrossRef] [PubMed]

49. Wang, X.; Wang, Y.; Zhou, Y.; Li, J.; Yin, W.; Wang, S.; Zhang, S.; Shen, J.; Shen, Z.; Wang, Y. Emergence of a Novel Mobile Colistin Resistance Gene, Mcr-8, in NDM-Producing Klebsiella Pneumoniae. Emerg. Microbes Infect. 2018, 7, 1-9. [CrossRef]

50. Nesporova, K.; Jamborova, I.; Valcek, A.; Medvecky, M.; Literak, I.; Dolejska, M. Various Conjugative Plasmids Carrying the Mcr-5 Gene in Escherichia coli Isolates from Healthy Chickens in Paraguay. J. Antimicrob. Chemother. 2019, 74, 3394-3397. [CrossRef]

51. Nation, R.L.; Li, J. Colistin in the 21st Century. Curr. Opin. Infect. Dis. 2009, 22, 535-543. [CrossRef]

52. Bengoechea, J.A.; Skurnik, M. Temperature-Regulated Efflux Pump/Potassium Antiporter System Mediates Resistance to Cationic Antimicrobial Peptides in Yersinia. Mol. Microbiol. 2000, 37, 67-80. [CrossRef]

53. Campos, M.A.; Vargas, M.A.; Regueiro, V.; Llompart, C.M.; Albertí, S.; Bengoechea, J.A. Capsule Polysaccharide Mediates Bacterial Resistance to Antimicrobial Peptides. IAI 2004, 72, 7107-7114. [CrossRef]

54. Makris, D.; Petinaki, E.; Tsolaki, V.; Manoulakas, E.; Mantzarlis, K.; Apostolopoulou, O.; Sfyras, D.; Zakynthinos, E. Colistin versus Colistin Combined with Ampicillin-Sulbactam for Multiresistant Acinetobacter baumannii Ventilator-Associated Pneumonia Treatment: An Open-Label Prospective Study. Indian J. Crit. Care Med. 2018, 22, 67-77. [CrossRef]

55. Ur Rahman, S.; Ali, T.; Ali, I.; Khan, N.A.; Han, B.; Gao, J. The Growing Genetic and Functional Diversity of Extended Spectrum Beta-Lactamases. Available online: https://www.hindawi.com/journals/bmri/2018/9519718/ (accessed on 10 December 2020).

56. Aruhomukama, D.; Najjuka, C.F.; Kajumbula, H.; Okee, M.; Mboowa, G.; Sserwadda, I.; Mayanja, R.; Joloba, M.L.; Kateete, D.P. BlaVIM- and BlaOXA-Mediated Carbapenem Resistance among Acinetobacter baumannii and Pseudomonas Aeruginosa Isolates from the Mulago Hospital Intensive Care Unit in Kampala, Uganda. BMC Infect Dis 2019, 19, 853. [CrossRef]

57. Caneiras, C.; Calisto, F.; Jorge da Silva, G.; Lito, L.; Melo-Cristino, J.; Duarte, A. First Description of Colistin and TigecyclineResistant Acinetobacter baumannii Producing KPC-3 Carbapenemase in Portugal. Antibiotics 2018, 7, 96. [CrossRef] [PubMed]

58. Turton, J.F.; Ward, M.E.; Woodford, N.; Kaufmann, M.E.; Pike, R.; Livermore, D.M.; Pitt, T.L. The Role of ISAba1 in Expression of OXA Carbapenemase Genes in Acinetobacter baumannii. FEMS Microbiol. Lett. 2006, 258, 72-77. [CrossRef] [PubMed]

59. Vila, J.; Martí, S.; Sánchez-Céspedes, J. Porins, Efflux Pumps and Multidrug Resistance in Acinetobacter baumannii. J. Antimicrob. Chemother. 2007, 59, 1210-1215. [CrossRef] [PubMed]

60. Poirel, L.; Nordmann, P. Carbapenem Resistance in Acinetobacter baumannii: Mechanisms and Epidemiology. Clin. Microbiol. Infect. 2006, 12, 826-836. [CrossRef] [PubMed]

61. Berg, E.S.; Wester, A.L.; Ahrenfeldt, J.; Mo, S.S.; Slettemeås, J.S.; Steinbakk, M.; Samuelsen, Ø.; Grude, N.; Simonsen, G.S.; Løhr, I.H.; et al. Norwegian Patients and Retail Chicken Meat Share Cephalosporin-Resistant Escherichia coli and IncK/BlaCMY-2 Resistance Plasmids. Clin. Microbiol. Infect. 2017, 23, 407.e9-407.e15. [CrossRef]

62. Song, H.-J.; Moon, D.C.; Mechesso, A.F.; Kang, H.Y.; Kim, M.H.; Choi, J.-H.; Kim, S.-J.; Yoon, S.-S.; Lim, S.-K. Resistance Profiling and Molecular Characterization of Extended-Spectrum/Plasmid-Mediated AmpC $\beta$-Lactamase-Producing Escherichia coli Isolated from Healthy Broiler Chickens in South Korea. Microorganisms 2020, 8, 1434. [CrossRef] 
63. Robberts, F.J.L.; Kohner, P.C.; Patel, R. Unreliable Extended-Spectrum $\beta$-Lactamase Detection in the Presence of Plasmid-Mediated AmpC in Escherichia coli Clinical Isolates. J. Clin. Microbiol. 2009, 47, 358-361. [CrossRef]

64. Stewart, A.G.; Harris, P.N.A.; Henderson, A.; Schembri, M.A.; Paterson, D.L. Oral Cephalosporin and $\beta$-Lactamase Inhibitor Combinations for ESBL-Producing Enterobacteriaceae Urinary Tract Infections. J. Antimicrob. Chemother. 2020, 75, $2384-2393$. [CrossRef]

65. Gordon, D.M.; Clermont, O.; Tolley, H.; Denamur, E. Assigning Escherichia coli Strains to Phylogenetic Groups: Multi-Locus Sequence Typing versus the PCR Triplex Method. Environ. Microbiol. 2008, 10, 2484-2496. [CrossRef]

66. Jafari, R.A.; Motamedi, H.; Maleki, E.; Ghanbarpour, R.; Mayahi, M. Phylogenetic Typing and Detection of Extended-Spectrum $\beta$-Lactamases in Escherichia coli Isolates from Broiler Chickens in Ahvaz, Iran. Vet. Res. Forum. 2016, 7, $227-233$.

67. Logue, C.M.; Wannemuehler, Y.; Nicholson, B.A.; Doetkott, C.; Barbieri, N.L.; Nolan, L.K. Comparative Analysis of Phylogenetic Assignment of Human and Avian ExPEC and Fecal Commensal Escherichia coli Using the (Previous and Revised) Clermont Phylogenetic Typing Methods and Its Impact on Avian Pathogenic Escherichia coli (APEC) Classification. Front. Microbiol. 2017, 8. [CrossRef] [PubMed]

68. Van Overbeek, L.S.; Wichers, J.H.; van Amerongen, A.; van Roermund, H.J.W.; van der Zouwen, P.; Willemsen, P.T.J. Circulation of Shiga Toxin-Producing Escherichia coli Phylogenetic Group B1 Strains Between Calve Stable Manure and Pasture Land With Grazing Heifers. Front. Microbiol. 2020, 11. [CrossRef] [PubMed]

69. Escobar-Páramo, P.; Menac'h, A.L.; Gall, T.L.; Amorin, C.; Gouriou, S.; Picard, B.; Skurnik, D.; Denamur, E. Identification of Forces Shaping the Commensal Escherichia coli Genetic Structure by Comparing Animal and Human Isolates. Environ. Microbiol. 2006, 8, 1975-1984. [CrossRef] [PubMed]

70. Ochoa, S.A.; Cruz-Córdova, A.; Luna-Pineda, V.M.; Reyes-Grajeda, J.P.; Cázares-Domínguez, V.; Escalona, G.; SepúlvedaGonzález, M.E.; López-Montiel, F.; Arellano-Galindo, J.; López-Martínez, B.; et al. Multidrug- and Extensively Drug-Resistant Uropathogenic Escherichia coli Clinical Strains: Phylogenetic Groups Widely Associated with Integrons Maintain High Genetic Diversity. Front. Microbiol. 2016, 7. [CrossRef]

71. Hashemizadeh, Z.; Kalantar-Neyestanaki, D.; Mansouri, S. Association between Virulence Profile, Biofilm Formation and Phylogenetic Groups of Escherichia coli Causing Urinary Tract Infection and the Commensal Gut Microbiota: A Comparative Analysis. Microb. Pathog. 2017, 110, 540-545. [CrossRef]

72. Landgraf, T.N.; Berlese, A.; Fernandes, F.F.; Milanezi, M.L.; Martinez, R.; Panunto-Castelo, A. The Ferric Aerobactin Receptor IutA, a Protein Isolated on Agarose Column, Is Not Essential for Uropathogenic Escherichia coli Infection. Rev. Lat. Am. Enferm. 2012, 20, 340-345. [CrossRef]

73. Johnson, T.J.; Wannemuehler, Y.M.; Nolan, L.K. Evolution of the Iss Gene in Escherichia coli. Appl. Environ. Microbiol. 2008, 74, 2360-2369. [CrossRef]

74. Benz, F.; Huisman, J.S.; Bakkeren, E.; Herter, J.A.; Stadler, T.; Ackermann, M.; Diard, M.; Egli, A.; Hall, A.R.; Hardt, W.-D.; et al. Plasmid- and Strain-Specific Factors Drive Variation in ESBL-Plasmid Spread In Vitro and In Vivo. ISME J. 2020. [CrossRef]

75. Jy, B.; Be, F. Plasmid Localization and Partition in Enterobacteriaceae. EcoSal Plus 2019, 8. [CrossRef]

76. Kubasova, T.; Cejkova, D.; Matiasovicova, J.; Sekelova, Z.; Polansky, O.; Medvecky, M.; Rychlik, I.; Juricova, H. Antibiotic Resistance, Core-Genome and Protein Expression in IncHI1 Plasmids in Salmonella Typhimurium. Genome Biol. Evol. 2016, 8, 1661-1671. [CrossRef]

77. Robertson, J.; Bessonov, K.; Schonfeld, J.; Nash, J.H.E. Universal Whole-Sequence-Based Plasmid Typing and Its Utility to Prediction of Host Range and Epidemiological Surveillance. Microb. Genom. 2020, 6. [CrossRef] [PubMed]

78. Rozwandowicz, M.; Brouwer, M.S.M.; Fischer, J.; Wagenaar, J.A.; Gonzalez-Zorn, B.; Guerra, B.; Mevius, D.J.; Hordijk, J. Plasmids Carrying Antimicrobial Resistance Genes in Enterobacteriaceae. J. Antimicrob. Chemother. 2018, 73, 1121-1137. [CrossRef] [PubMed]

79. Botelho, L.A.B.; Kraychete, G.B.; Rocha, P.B.; de Souza da-Silva, A.P.; Picão, R.C.; Moreira, B.M.; Bonelli, R.R. CTX-M- and PAmpC-Encoding Genes Are Associated with Similar Mobile Genetic Elements in Escherichia coli Isolated from Different Brands of Brazilian Chicken Meat. Microb. Drug Resist. 2019, 26, 14-20. [CrossRef] [PubMed]

80. Kaesbohrer, A.; Bakran-Lebl, K.; Irrgang, A.; Fischer, J.; Kämpf, P.; Schiffmann, A.; Werckenthin, C.; Busch, M.; Kreienbrock, L.; Hille, K. Diversity in Prevalence and Characteristics of ESBL/PAmpC Producing E. Coli in Food in Germany. Vet. Microbiol. 2019, 233, 52-60. [CrossRef]

81. Maamar, E.; Hammami, S.; Alonso, C.A.; Dakhli, N.; Abbassi, M.S.; Ferjani, S.; Hamzaoui, Z.; Saidani, M.; Torres, C.; Boutiba-Ben Boubaker, I. High Prevalence of Extended-Spectrum and Plasmidic AmpC Beta-Lactamase-Producing Escherichia coli from Poultry in Tunisia. Int. J. Food Microbiol. 2016, 231, 69-75. [CrossRef]

82. Pietsch, M.; Irrgang, A.; Roschanski, N.; Brenner Michael, G.; Hamprecht, A.; Rieber, H.; Käsbohrer, A.; Schwarz, S.; Rösler, U.; Kreienbrock, L.; et al. Whole Genome Analyses of CMY-2-Producing Escherichia coli Isolates from Humans, Animals and Food in Germany. BMC Genom. 2018, 19, 601. [CrossRef]

83. Moran, R.A.; Hall, R.M. Evolution of Regions Containing Antibiotic Resistance Genes in FII-2-FIB-1 ColV-Colla Virulence Plasmids. Microb. Drug Resist. 2017, 24, 411-421. [CrossRef]

84. Turton, J.; Davies, F.; Turton, J.; Perry, C.; Payne, Z.; Pike, R. Hybrid Resistance and Virulence Plasmids in "High-Risk" Clones of Klebsiella Pneumoniae, Including Those Carrying BlaNDM-5. Microorganisms 2019, 7, 326. [CrossRef] 